\title{
Vida e comunicação cotidianas no capitalismo da coronavírus ${ }^{1}$ \\ Everyday life and everyday communication in coronavirus capitalism
}

\author{
CHRISTIA N FUCHSa \\ University of Westminster, Instituto de Pesquisa de Comunicação e Mídia, Instituto Westminster de \\ Estudos Avançados. Londres, Reino Unido
}

\section{RESUMO}

Em 2020, a crise da coronavírus provocou uma ruptura nas sociedades e na vida cotidiana em todo o mundo. Este artigo é uma contribuição para a teorização crítica das mudanças pelas quais as sociedades passaram à luz da crise. Para isso, indaga: como a vida e a comunicação cotidianas mudaram nesse período? Como o capitalismo as configura durante essa crise? Organizado em seções, enfoca, na segunda, as maneiras como o espaço social, a vida e a comunicação cotidianas mudaram na crise da coronavírus. Já a terceira concentra-se na comunicação da ideologia no contexto da coronavírus, analisando a comunicação de narrativas de conspiração e notícias falsificadas sobre o vírus.

Palavras-chave: Coronavírus, vida cotidiana, comunicação cotidiana, teoria crítica, teoria crítica da comunicação

\begin{abstract}
In 2020, the coronavirus crisis ruptured societies and their everyday life around the globe. This article is a contribution to critically theorising the changes societies have undergone in the light of the crisis. It asks: How have everyday life and everyday communication changed in the coronavirus crisis? How does capitalism shape everyday life and everyday communication during this crisis? Organized in sections, the second one focuses on how social space, everyday life, and everyday communication have changed during the coronavirus crisis. The third one focuses on the communication of ideology in the context of coronavirus by analyzing the communication of coronavirus conspiracy stories and false coronavirus news.
\end{abstract}

Keywords: Coronavirus, everyday life, everyday communication, critical theory, critical theory of communication

ical theory, critical theory of communication

\author{
${ }^{1}$ Artigo publicado \\ originalmente em tripleC \\ (2020), 18(1), 375-399. https:// \\ doi.org/10.31269/triplec. \\ v18i1.1167. Tradução de \\ Richard Romancini. \\ ${ }^{a}$ Coeditor da revista científica \\ tripleC: Communication, \\ Capitalism \& Critique, \\ teórico crítico da sociedade \\ e da comunicação e autor de \\ vários livros e artigos. Orcid: \\ https://orcid.org/0000-0003- \\ 0589-4579. E-mail: C.Fuchs@ \\ westminster.ac.uk
}




\section{INTRODUÇÃO}

DOENÇA DO CORONAVÍRUS (Covid-19) pode ser definida como u um mal respiratório altamente infeccioso. Seu nome deriva do fato 1 de que, sob o microscópio, parece uma coroa. O vírus é altamente contagioso e tem uma taxa de mortalidade várias vezes maior que a da gripe comum. Os sintomas comuns incluem febre, tosse seca, dificuldade respiratória e cansaço extremo. A maioria dos casos tem desenvolvimento leve, mas, em outros, ocorre grave pneumonia, que pode ser fatal.

O primeiro paciente com a doença foi identificado em $1^{\circ}$ de dezembro de 2019, em Wuhan, uma cidade com mais de onze milhões de habitantes na província chinesa de Hubei. No final de janeiro de 2020, havia quase doze mil casos relatados na China continental ("Coronavirus pandemic in mainland China", 2020). Devido ao caráter global e em rede das sociedades contemporâneas, o novo coronavírus (SARS-CoV-2, referido como coronavírus neste artigo) se espalhou pelo mundo em um curto período de tempo.

A experiência prévia mostrou que uma das desvantagens da crescente globalização é a impossibilidade de impedir a rápida difusão internacional de novas doenças. Vivemos em um mundo altamente conectado, onde quase todos viajam. As redes humanas para a difusão potencial são vastas e claras. (Harvey, 2020, para. 6)

Em 11 de março de 2020, a Organização Mundial da Saúde (OMS) declarou como uma pandemia a coronavírus. Em 29 de março de 2020, havia 638.146 casos da doença confirmados - distribuídos em um total de 203 países - os quais resultaram em 30.105 mortes (https://bit.ly/3brZQvJ).

Como reação às ameaças do vírus à humanidade e às vidas humanas, muitos países introduziram medidas de saúde pública de amplo alcance, como proibições à circulação pública de pessoas e medidas de distanciamento social. Este artigo é uma contribuição analítica à teoria social das implicações da crise da coronavírus para a sociedade. Indaga-se: como a vida e a comunicação cotidianas mudaram na crise da coronavírus? Como o capitalismo configura a vida e a comunicação cotidianas durante esta crise?

A seção 2 aborda como o espaço social e a comunicação cotidiana mudaram devido à crise da coronavírus. A seção 3 enfoca a comunicação da ideologia no contexto da coronavírus, analisando a comunicação de narrativas conspiratórias e notícias falsificadas sobre a doença. 


\section{COMUNICAÇÃO E SOCIABILIDADE COTIDIANAS NA CRISE DA CORONAVÍRUS}

Enquanto não houver vacina contra a coronavírus, o vírus representa um perigo para a vida de todos os seres humanos e de suas sociedades, uma vez que é altamente contagioso e tem uma taxa de mortalidade relativamente alta, muitas vezes maior do que a da gripe comum.

A fim de combater a pandemia, a OMS (2020) recomenda

que o distanciamento social e as medidas de quarentena devem ser implementadas de maneira oportuna e rígida. Algumas das medidas que os países podem considerar são: fechamento de escolas e universidades, implementação de políticas de trabalho remoto, diminuição do uso de transporte público nos horários de pico e adiamento de viagens não essenciais. (para. 8)

\section{O darwinismo social de Boris Johnson}

Como reação à pandemia, o distanciamento social foi implementado como medida de saúde pública em muitos países. Alguns tomaram medidas duras, como toque de recolher, enquanto outros apenas recomendaram o distanciamento social, mas não o impuseram legalmente. Alguns países mudaram suas políticas. O governo conservador de Boris Johnson no Reino Unido primeiro adotou uma abordagem laissez-faire. Não restringiu a vida pública. Posteriormente, tomou medidas comuns em muitos países da Europa continental, como o fechamento de escolas e negócios não essenciais, a proibição de eventos públicos e a determinação para que as pessoas ficassem em casa.

Em uma entrevista coletiva, em 12 de março, Johnson disse que devido à coronavírus "muitas famílias vão perder seus entes queridos antes do tempo". Em paralelo, não tomou medidas proibindo a circulação pública, como outros países já haviam feito na época. A estratégia anunciada por ele, junto com seus assessores científicos e médicos, era baseada em não conter o vírus, deixando-o se espalhar até que a "imunidade de rebanho" fosse alcançada. O diretor do Departamento de Saúde Chris Whitty argumentou que "nossa base principal de planejamento é de até $80 \%$ da população infectada”. Uma vez que o Reino Unido tem 66 milhões de habitantes e a taxa de mortalidade por coronavírus é em média de um por cento, isso implicaria deixar mais de 500 mil pessoas morrerem da doença para atingir o que, no jargão médico, é chamado de imunidade de rebanho. Em uma entrevista à Sky News, o Conselheiro Científico Patrick Vallace defendeu essa abordagem dizendo que "é claro que encaramos a perspectiva de, como disse o primeiro-ministro 
ontem, um número crescente de pessoas morrerem. . . . Essa é uma doença horrível" (Sky News, 2020).

Johnson e seu principal conselheiro médico e científico escolheram uma abordagem darwinista social, na qual os mais aptos sobrevivem enquanto o governo tolera que outros morram, embora medidas de saúde pública pudessem reduzir a quantidade e a proporção de óbitos. O meio-primo de Charles Darwin, Francis Galton (1822-1911) (1909), argumentou que a sociedade deveria se basear "no funcionamento da Natureza, garantindo que a humanidade seja representada pelo mais apto" (p. 42). Assim como o thatcherismo desenvolvido pelos conservadores defende e pratica a sobrevivência das empresas mais aptas na economia capitalista, Johnson e seus conselheiros planejaram usar o mesmo princípio para a política demográfica. A conclusão é que aqueles que estão velhos, fracos e doentes são sacrificados. Em uma sociedade radicalmente neoliberal como o Reino Unido e os EUA, o conceito darwinista de Alfred Russel Wallace (1889/2009) de natureza é aplicado à sociedade: na crise da coronavírus, o "melhor organizado, ou o mais saudável, ou o mais ativo, ou o melhor protegido, ou o mais inteligente, inevitavelmente, no longo prazo, ganhará uma vantagem sobre aqueles com menores qualidades desse tipo; ou seja, o mais apto sobreviverá" (p. 123).

\section{Distanciamento social}

Os humanos são seres sociais e societários. Vivem nas e por meio das relações sociais na sociedade. A comunicação é o processo de produção e reprodução da sociabilidade, relações sociais, estruturas sociais, sistemas sociais e sociedade (Fuchs 2020a). Em uma relação social, pelo menos dois humanos tiram sentido das ações um do outro. Cada um deles interpreta o que o outro está fazendo, levando pelo menos a novos pensamentos e, potencialmente, essa interação provoca mudanças no sistema social. A medida de distanciamento social praticada como resposta à crise da coronavírus não significa a dissolução, mas a reorganização radical das relações sociais. Os seres humanos evitam as relações sociais face a face e as substituem por relações sociais mediadas, nas quais a comunicação se organiza com a ajuda do telefone, da mídia social, dos aplicativos de mensagens e softwares de comunicação de vídeo como WhatsApp, Telegram, Zoom, Skype, Panopto, Blackboard Collaborate, Jitsi, Discord etc. O distanciamento social não significa revogar, mas substituir a comunicação face a face - que carrega o risco de contágio - pela comunicação mediada. A mediação torna-se uma estratégia de distanciamento e sobrevivência. O distanciamento social não é 
um distanciamento do social e de outros humanos, mas sim comunicação e sociabilidade exercidas à distância.

Em 2020, bilhões de humanos experimentaram e praticaram a ruptura e a reorganização radical de sua vida social. Na sociedade moderna, organizamos nossa vida cotidiana a partir de práticas sociais que ocorrem em distintos sistemas sociais, nos quais, repetidamente, de forma rotinizada, passamos certos períodos de tempo juntos com os outros, para atingir certos objetivos. Os principais sistemas sociais de nossa vida cotidiana incluem o lar, o ambiente de trabalho e as organizações educacionais (creche, escola, universidade). Existem, além disso, espaços públicos acessíveis a todos, onde passamos os momentos de lazer, encontramos outras pessoas, nos deslocamos de um lugar para outro ou organizamos outros aspectos de nossa vida cotidiana. Esses espaços incluem parques, playgrounds, cafés, trens, ônibus, metrô, lojas etc.

A divisão do trabalho e das atividades significa que os humanos passam certos períodos do dia em determinados espaços. Um exemplo é o trabalho em um escritório ou fábrica, de segunda a sexta-feira, das $9 \mathrm{~h}$ às $17 \mathrm{~h}$. Isso significa que o espaço e o tempo são distribuídos em períodos específicos vividos em certos locais. A flexibilização, a globalização, a digitalização, a individualização e a neoliberalização da sociedade capitalista transformaram o espaço-tempo da vida cotidiana. Cada vez mais pessoas trabalham em diferentes espaços, incluindo suas casas e espaços públicos, em diferentes momentos. O local de trabalho, a casa e os espaços públicos convergiram parcialmente. As fronteiras entre tempo de lazer e tempo de trabalho; diversão e trabalho; consumo e produção; escritório e moradia etc. foram borradas. Para muitas pessoas, essa tendência tem significado um aumento do tempo de trabalho e a extensão da lógica do capital para esferas alheias ao local de trabalho tradicional. Cada vez mais pessoas tiveram que trabalhar mais para sobreviver, mas fazem isso apenas de maneiras precárias.

\section{A transformação radical do espaço-tempo da vida cotidiana}

A crise da coronavírus provocou uma transformação radical do espaço-tempo da vida cotidiana. Locais de trabalho e espaços públicos foram fechados. A diferenciação física e social dos espaços da vida cotidiana entrou em colapso quando esses, de repente, convergiram completamente para o lar enquanto espaço da vida cotidiana. O entrelaçamento e a convergência dos espaços sociais promovidos pelo neoliberalismo foram subitamente levados a seu extremo. Os espaços intermediários da vida pública, onde antes passávamos os tempos de 
lazer e de locomoção, como cafés, restaurantes, parques, natureza, transportes públicos etc. esvaziaram-se, criando cidades vazias e espaços urbanos fantasmas.

Os políticos tiveram que decidir entre duas opções básicas de gestão política à luz da crise da coronavírus, ou seja, alterar radicalmente a vida cotidiana e pedir à maioria dos cidadãos para ficar em casa ou mudar minimamente $o$ cotidiano. A primeira opção tenta salvar vidas humanas, reduzindo a comunicação e as relações sociais diretas, tanto quanto possível, gerando, portanto, uma inevitável crise econômica. A segunda opção mantém a comunicação e as relações sociais diretas, colocando as vidas humanas em risco na tentativa de evitar uma crise econômica.

Em crises existenciais como a da coronavírus, as estratégias políticas neoliberais optam por manter a maioria dos negócios abertos. Em contraste, as estratégias de governo socialistas fecham todos os negócios não essenciais para garantir a sobrevivência da sociedade. No segunda caso, a vida humana e o bem-estar estão acima dos interesses econômicos. No primeiro, ao contrário, $\mathrm{o}$ crescimento econômico e o lucro são colocados acima da vida humana.

O espaço social é estruturado e regionalizado em localidades específicas. Estas são as localizações de espaço-tempo, as zonas, as estações e os lugares como casas, ruas, cidades, locais de trabalho, escolas, creches, parques, lojas, restaurantes, cafés, meios de transporte público etc.

Os locais referem-se ao uso do espaço para fornecer os cenários da interação que, por sua vez, são essenciais para especificar sua contextualidade.... As localidades podem variar de um cômodo em uma casa, uma esquina, o chão de fábrica de uma empresa, vilas e cidades, até as áreas territorialmente demarcadas ocupadas por estados-nações. Mas os locais são tipicamente regionalizados internamente, $\mathrm{e}$ as regiões dentro deles são de importância crítica na constituição dos contextos de interação. (Giddens, 1984, p. 118)

Um local é um espaço físico ou virtual determinado, o qual é usado em certo momento, normalmente de forma rotinizada, implicando repetição, para ações sociais e de comunicação com objetivo específico. O espaço-tempo é organizado na forma de zonas ou regiões demarcadas e delimitadas (locais) que são o contexto físico, espacial e temporal de tipos específicos de ação e comunicação. Os locais são os lugares e os cenários físicos das práticas comunicativas dos seres humanos.

$\mathrm{Na}$ crise da coronavírus, os espaços sociais e locais de trabalho, lazer, educação; a esfera pública; a esfera privada; as amizades e a família convergem no local do lar. A casa é, ao mesmo tempo, local de trabalho, espaço familiar e 
privado, escola, creche, espaço de lazer, natural e público a partir do qual nos conectamos aos amigos e contatos profissionais etc. Os espaços sociais convergem na moradia. Nesse espaço social convergente, organizar a vida cotidiana pode facilmente se tornar difícil ao dividir o tempo em pequenas frações, cada uma delas dedicada a atividades específicas conforme a rotina. Na crise da coronavírus, o lar tornou-se o supralocal da vida cotidiana.

Enquanto o dia costumava ser, para muitos indivíduos, o horário de trabalho, na era da crise da coronavírus deve ser simultaneamente horário de trabalho, de diversão, de educação, de convívio familiar, de compras, de trabalho doméstico, de lazer, de cuidado, atenção psicológica etc. A convergência de espaços sociais na moradia é acompanhada pela convergência de períodos de tempo dedicados a atividades específicas. O resultado é que as atividades que os humanos normalmente realizam a partir de diferentes papéis sociais em momentos e em locais diversos convergem para atividades realizadas em um espaço-tempo universal, tendencialmente não zoneado e não estruturado em um local, o lar.

\section{A sobrecarga do indivíduo}

Essa convergência pode facilmente resultar em uma sobrecarga para o indivíduo que não pode gerenciar vários papéis sociais ao mesmo tempo em um local. A situação é agravada pelos fardos psicológicos excepcionais provocados pela crise da coronavírus. Os indivíduos se preocupam com a vida de sua família, dos amigos e deles próprios, tendo que pensar em como organizar atividades cotidianas, tais como fazer compras e sair sem arriscar a própria vida e a de outros, lidando com a falta de proximidade física com seus familiares, pais e amigos, dedicando tempo para apoiar pessoas idosas, fracas e doentes de suas famílias e comunidades isoladas etc. Em tal situação de crise, grande parte do tempo é utilizado para a sobrevivência, em atividades que garantem a manutenção física, psicológica e social imediata. As atividades de rotina tornam-se tarefas desafiadoras às quais uma quantidade significativa de tempo precisa ser dedicada.

O trabalho de sobrevivência dá forma à vida cotidiana na crise da coronavírus. Dado que a comunicação direta é limitada, mais tempo precisa ser gasto na organização da comunicação à distância. Há momentos em que os indivíduos não são capazes de prosseguir e "funcionar" adequadamente, porque têm que lidar com o medo da morte, da doença e do futuro. Em tempos de crise, os humanos gostam de se reunir com seus companheiros mais próximos para ajudar e apoiar uns aos outros. Nessa crise, porém, a proximidade física 
em grupos maiores é desencorajada, já que aumenta os riscos de contágio, doença e morte. O distanciamento social representa um fardo psicológico para muitas pessoas, pois não podem estar fisicamente próximas de alguns ou de vários de seus entes queridos. A comunicação mediada pode fornecer algum suporte emocional, mas carece da capacidade de tocar, sentir, cheirar, abraçar etc. É possível dizer belas palavras a um amigo ou parente por meio de uma webcam, mas não se pode olhá-lo nos olhos, o que faz parte da comunicação empática. A proximidade física é um aspecto importante do cuidado que está faltando na crise da coronavírus, e isso representa uma carga psicológica adicional para os indivíduos. É muito mais difícil comunicar emoções, amor, solidariedade e empatia na comunicação mediada do que na comunicação face a face.

Tradicionalmente, os trabalhadores domésticos têm que lidar, ao mesmo tempo, com vários tipos de trabalho - incluindo cuidados, educação, limpeza, cozinha, compras etc. - no local de casa. Em certo sentido, a crise da coronavírus é um processo de domestificação radical em massa que confina o trabalho, a ação social e a comunicação no espaço do lar. Esta condição é característica das trabalhadoras domésticas há muito tempo (Mies et al., 1988).

É decisivo como o Estado age em tal situação de profunda emergência. Existe um continuum da ação estatal que vai da ação neoliberal à socialista. A ação estatal neoliberal tolera o desemprego e a precariedade dos trabalhadores, preocupando-se apenas em salvar as empresas. Não garante a seguridade social, o sustento, a renda, os pagamentos de aluguel e a sobrevivência da classe trabalhadora. A ação estatal socialista, em contraste, assegura a sobrevivência dessa classe por meio de medidas como uma renda básica incondicional durante o tempo de crise, a continuação do pagamento de salários para trabalhadores registrados e autônomos, congelamento de aluguéis etc.

A ação socialista na crise garante que os seres humanos tenham o tempo e os recursos necessários para sobreviver à crise sem se tornarem pobres, endividados, falidos etc. Reconhece a necessidade de os humanos terem tempo suficiente para dedicar ao trabalho de sobrevivência. Fornece as bases materiais necessárias para esse trabalho.

A ação neoliberal na crise tolera o aumento da pobreza, da miséria, da dívida, da precariedade, da falta de moradia, do desemprego etc. para reorganizar a sociedade em prol do capital em um estado de emergência. Pensar essa lógica até as últimas consequências implica que a gestão neoliberal da crise estabelece uma ditadura do capital organizada pelo Estado que escraviza a classe trabalhadora empobrecida, endividada e precária em sua luta para sobreviver. A crise da coronavírus é uma crise existencial e 
de ruptura da sociedade que apresenta potenciais para o desenvolvimento do socialismo e da solidariedade, de um lado, e da escravidão e da ditadura fascista, do outro.

\section{Espaço social, vida e comunicação cotidianas na crise da coronavírus}

Com base na teoria do espaço do filósofo francês Henri Lefebvre (1974/1991), o teórico crítico David Harvey (2005) produz uma tipologia do espaço social (ver tabela 1). Usando a distinção de Lefebvre entre espaços percebidos, concebidos e vividos como três dimensões do espaço, Harvey distingue o espaço físico, as representações do espaço e os espaços de representação. Ele adiciona à teoria de Lefebvre a distinção entre espaço absoluto, relativo e relacional. Os espaços são absolutos por serem locais com certos limites físicos. São relativos, pois os objetos inseridos neles possuem certas distâncias uns dos outros. E são relacionais, porque esses objetos se relacionam uns com os outros. Na sociedade, os humanos produzem e reproduzem o espaço social por uma dialética de práticas e estruturas sociais. Os campos da tabela 1 descrevem aspectos particulares do espaço social.

Tabela 1. Tipologia do espaço social de David Harvey (2005)

\begin{tabular}{|c|c|c|c|}
\hline & $\begin{array}{c}\text { Espaço físico } \\
\text { (espaço experienciado) }\end{array}$ & $\begin{array}{l}\text { Representação do espaço } \\
\text { (espaço conceitualizado) }\end{array}$ & $\begin{array}{c}\text { Espaços de representação } \\
\text { (espaço vivido) }\end{array}$ \\
\hline $\begin{array}{l}\text { Espaço } \\
\text { absoluto }\end{array}$ & local físico & $\begin{array}{l}\text { símbolos, mapas e planos } \\
\text { dos espaços físicos }\end{array}$ & $\begin{array}{l}\text { locais como espaços } \\
\text { sociais onde os humanos } \\
\text { vivem, trabalham e } \\
\text { comunicam }\end{array}$ \\
\hline $\begin{array}{l}\text { Espaço } \\
\text { relativo } \\
\text { (tempo) }\end{array}$ & $\begin{array}{l}\text { humanos em um espaço } \\
\text { local }\end{array}$ & $\begin{array}{l}\text { símbolos usados e } \\
\text { significados criados pelos } \\
\text { humanos em locais físicos }\end{array}$ & $\begin{array}{l}\text { humanos como atores } \\
\text { sociais agindo em papéis } \\
\text { sociais }\end{array}$ \\
\hline $\begin{array}{l}\text { Espaço } \\
\text { relacional } \\
\text { (tempo) }\end{array}$ & $\begin{array}{l}\text { relações sociais dos } \\
\text { humanos em um local } \\
\text { físico }\end{array}$ & $\begin{array}{l}\text { linguagem como estrutura } \\
\text { social e societal }\end{array}$ & $\begin{array}{l}\text { práticas comunicativas } \\
\text { que produzem e } \\
\text { reproduzem relações } \\
\text { sociais, sociabilidade e } \\
\text { espaços sociais }\end{array}$ \\
\hline
\end{tabular}

A tabela 2 mostra como os espaços sociais estão se modificando e se organizando na crise da coronavírus. 
Tabela 2. Espaço social na crise da coronavírus

\begin{tabular}{|c|c|c|c|}
\hline & $\begin{array}{c}\text { Espaço físico } \\
\text { (espaço experienciado) }\end{array}$ & $\begin{array}{l}\text { Representação do espaço } \\
\text { (espaço conceitualizado) }\end{array}$ & $\begin{array}{c}\text { Espaços de representação } \\
\text { (espaço vivido) }\end{array}$ \\
\hline $\begin{array}{l}\text { Espaço } \\
\text { absoluto }\end{array}$ & lar como o supralocal & $\begin{array}{l}\text { planos e estratégias para } \\
\text { como usar o supralocal da } \\
\text { casa para a organização } \\
\text { da vida cotidiana }\end{array}$ & $\begin{array}{l}\text { o lar como o espaço } \\
\text { social dominante e } \\
\text { espaço suprassocial } \\
\text { onde os humanos } \\
\text { simultaneamente } \\
\text { organizam os múltiplos } \\
\text { aspectos de sua vida e } \\
\text { trabalho, convergência de } \\
\text { espaços absolutos no lar. }\end{array}$ \\
\hline $\begin{array}{l}\text { Espaço } \\
\text { relativo } \\
\text { (tempo) }\end{array}$ & $\begin{array}{l}\text { humanos permanecem } \\
\text { predominantemente em } \\
\text { um local, suas casas }\end{array}$ & $\begin{array}{l}\text { símbolos usados e } \\
\text { significados criados pelos } \\
\text { humanos no supralocal } \\
\text { da casa }\end{array}$ & $\begin{array}{l}\text { Convergência dos papéis } \\
\text { sociais humanos no } \\
\text { supraespaço do lar }\end{array}$ \\
\hline $\begin{array}{l}\text { Espaço } \\
\text { relacional } \\
\text { (tempo) }\end{array}$ & $\begin{array}{l}\text { relações sociais em uma } \\
\text { distância física organizada } \\
\text { por meio das tecnologias } \\
\text { de comunicação entre } \\
\text { locais domésticos }\end{array}$ & $\begin{array}{l}\text { linguagem como estrutura } \\
\text { social }\end{array}$ & $\begin{array}{l}\text { a convergência das } \\
\text { práticas comunicativas } \\
\text { dos humanos em um } \\
\text { espaço convergente e } \\
\text { sob condições de tempo } \\
\text { convergente no lar, } \\
\text { mediação da convergência } \\
\text { de espaço-tempo } \\
\text { pelas tecnologias de } \\
\text { comunicação }\end{array}$ \\
\hline
\end{tabular}

Na crise da coronavírus, os humanos, em grande parte, estão confinados ao espaço físico do lar, para o qual certas estratégias organizacionais são necessárias para que a vida cotidiana possa ser organizada a partir do domicílio. Os seres humanos experimentam, conceituam, vivem e, portanto, também produzem o espaço-tempo social de maneiras que fazem os espaços sociais convergirem no supratempo-espaço do lar. As tecnologias de comunicação desempenham um papel decisivo na organização da vida cotidiana a partir do lar na crise da coronavírus.

A vida cotidiana remete às práticas sociais dentro da totalidade da sociedade (Lefebvre, 2002, p. 31). Ela é um "nível intermediário e mediador" da sociedade (p. 45). Lefebvre (2002) identifica três dimensões da vida cotidiana: as formas naturais de necessidade, o domínio econômico da apropriação de objetos e bens e o âmbito da cultura (p. 62). Portanto, Lefebvre vê a natureza, a economia e a cultura como os três domínios importantes da vida cotidiana. O que falta é o domínio da política, no qual os humanos tomam decisões coletivas que são compulsórias para todos, assumindo a forma de normas. A crítica da vida cotidiana analisa como os humanos vivem, "quão mal vivem, ou como não vivem, 
de qualquer modo" (p. 18). Lefebvre argumenta que, em fases de mudança social profunda, "a vida cotidiana é suspensa, estilhaçada ou transformada" (p. 109). A crise da coronavírus suspendeu, estilhaçou e exigiu a reorganização das práticas, estruturas e rotinas da vida cotidiana.

Tabela 3. Distinção de Lefebvre entre o vivido e o viver

\begin{tabular}{cc}
\hline O vivido (le vécu) & O viver (le vivre) \\
\hline individual & grupo \\
\hline experiência, conhecimento, fazer & contexto, horizonte \\
prática & estruturas \\
presente & presença \\
\hline
\end{tabular}

Nota. Adaptado de Lefebvre (2002, p. 166, pp. 216-218).

Lefebvre distingue entre o vivido (le vécu) e o viver (le vivre) como dois níveis da vida cotidiana (ver tabela 3 ). A figura 1 mostra um modelo da vida cotidiana.

No nível da realidade vivida, os seres humanos produzem objetos sociais por meio de práticas comunicativas. Eles o fazem sob as condições de vida, ou seja, as condições estruturais que permitem e restringem as práticas humanas, a produção e a comunicação. $O$ nível do viver consiste em uma interação de estruturas, sistemas e instituições sociais. Todas essas têm dimensões econômicas, políticas e culturais. Em muitos sistemas sociais, uma dessas dimensões é dominante para que possamos diferenciar estruturas/sistemas/instituições econômicas, políticas e culturais. No nível da vida vivida, os humanos se relacionam por meio de práticas comunicativas. Essas práticas comunicativas são as bases da produção, reprodução e diferenciação de estruturas/sistemas/instituições econômicas, políticas e culturais que condicionam as práticas humanas. Existe uma dialética do viver e do vivido em qualquer sociedade. Esta é uma dialética de sujeitos humanos e objetos sociais. 


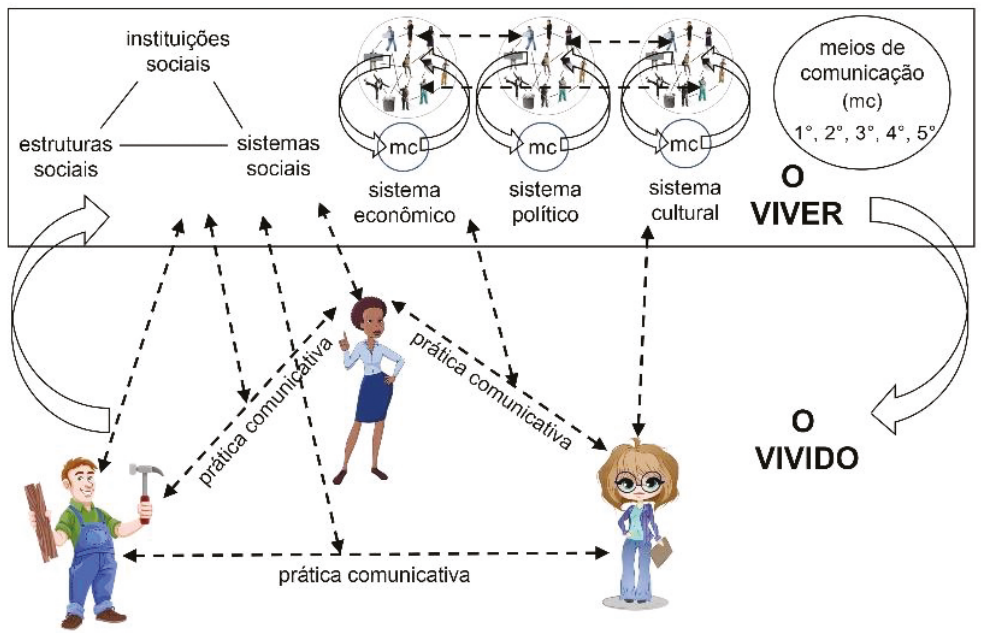

Figura 1

Vida e comunicação cotidianas

Os meios de comunicação medeiam a dialética de objetos e sujeitos e as relações entre os seres humanos. Podemos distinguir cinco tipos de meios de comunicação (tabela 4).

Tabela 4. Cinco tipos de meios de comunicação

\begin{tabular}{|c|c|c|}
\hline & Papel da mediação por tecnologia & Exemplos \\
\hline $\begin{array}{l}\text { Tecnologias de } \\
\text { comunicação } \\
\text { primárias }\end{array}$ & $\begin{array}{l}\text { Corpo e mente humanos, nenhuma } \\
\text { tecnologia de mídia é usada para a } \\
\text { produção, distribuição, recepção } \\
\text { de informações }\end{array}$ & $\begin{array}{l}\text { Teatro, concerto, apresentação, } \\
\text { comunicação interpessoal }\end{array}$ \\
\hline $\begin{array}{l}\text { Tecnologias de } \\
\text { comunicação } \\
\text { secundárias }\end{array}$ & $\begin{array}{l}\text { Uso de tecnologia de mídia para } \\
\text { produção de informação }\end{array}$ & $\begin{array}{l}\text { Jornais, revistas, livros, } \\
\text { arte e cultura produzidas } \\
\text { tecnologicamente }\end{array}$ \\
\hline $\begin{array}{l}\text { Tecnologias de } \\
\text { comunicação } \\
\text { terciárias }\end{array}$ & $\begin{array}{l}\text { Uso de tecnologia de mídia } \\
\text { para a produção e consumo de } \\
\text { informação, não para distribuição }\end{array}$ & $\begin{array}{l}\text { CDs, DVDs, fitas, discos, discos } \\
\text { Blu-ray, discos rígidos }\end{array}$ \\
\hline $\begin{array}{l}\text { Tecnologias de } \\
\text { comunicação } \\
\text { quaternárias }\end{array}$ & $\begin{array}{l}\text { Uso de tecnologia de mídia para a } \\
\text { produção, distribuição e consumo } \\
\text { de informação }\end{array}$ & $\mathrm{TV}$, rádio, filme, telefone, internet \\
\hline $\begin{array}{l}\text { Tecnologias de } \\
\text { comunicação } \\
\text { quinárias }\end{array}$ & $\begin{array}{l}\text { Tecnologias prossumidoras de } \\
\text { mídia digital, conteúdo gerado pelo } \\
\text { usuário }\end{array}$ & Internet, mídia social \\
\hline
\end{tabular}

A figura 2 mostra a transformação da vida e da comunicação cotidianas durante a crise da coronavírus. Os humanos se isolam e, portanto, evitam relações comunicativas diretas. Essa circunstância é visualizada no nível do vivido por 
indivíduos e pequenos grupos enclausurados. As densas redes de comunicação e relações sociais diretas são suspensas. No nível estrutural do vivido, as dimensões econômica, política e cultural não se organizam como locais separados, mas tendem a convergir no sistema social do lar que assume a forma de um supralocal a partir do qual a vida econômica, política e cultural é organizada e estruturada à distância. Os seres humanos passam a maior parte do tempo em isolamento físico em suas casas, de onde acessam e arranjam estruturas sociais, sistemas e instituições à distância, fazendo uso de meios de comunicação secundários, terciários, quaternários e quinários. Evita-se a utilização dos meios primários de comunicação, nomeadamente a comunicação face a face. Enquanto, em condições normais, os seres humanos organizam a economia, a política e cultura na forma de sistemas sociais separados aos quais acessam na vida cotidiana ao se deslocarem para diferentes locais físicos especializados, na crise da coronavírus os locais físicos especializados são impedidos. Os papéis sociais estruturais desses sistemas são preservados: uma multidão de humanos nos locais físicos de suas residências organiza esses sistemas à distância com a ajuda da comunicação mediada. Os seres humanos dificilmente se comunicam cara a cara, mas por meio de tecnologias de comunicação mediadas.

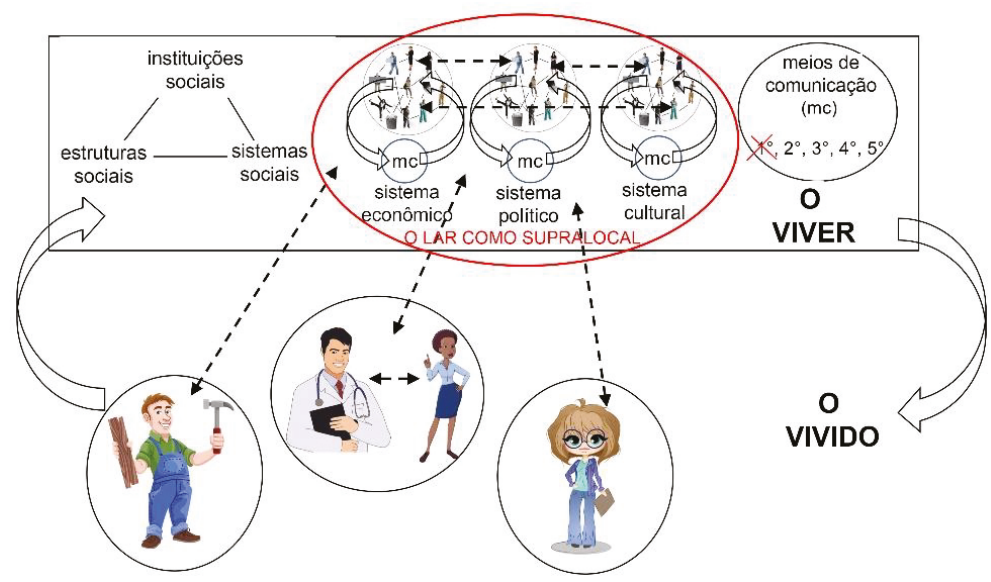

Figura 2

Vida e comunicação cotidianas na crise da coronavírus

\section{A crise da coronavírus como desaceleração da vida cotidiana?}

$\mathrm{Na}$ crise da coronavírus, a maioria das pessoas percorre apenas distâncias físicas pequenas e menos mercadorias são transportadas, de modo que a vida cotidiana é desacelerada, chegando a uma relativa paralisia. Há menos pessoas por menos 
tempo nas ruas, em espaços públicos e intermediários. Ao mesmo tempo, aumenta enormemente o número de atividades sociais e práticas comunicativas realizadas em casa e conduzidas à distância. Como consequência, as redes de comunicação, como a internet e as redes de telefonia móvel, são utilizadas em sua capacidade máxima. A diminuição da atividade social em espaços públicos corresponde ao fortalecimento e multiplicação das atividades sociais que ocorrem no domicílio e localmente. A crise da coronavírus desglobaliza e, portanto, localiza a vida cotidiana.

O sociólogo alemão Hartmut Rosa (2020b) defende que a crise do vírus corona significa "desaceleração forçada" (para. 8). Ele argumenta que há uma “desaceleração massiva da vida física real, onde por um lado a pessoa se sente silenciada e excluída, mas, por outro lado, descobre novas formas de solidariedade e de afabilidade" (para. 16). Rosa (2020a) está bastante otimista com as consequências da crise da coronavírus. Por um lado, vê a perda da segurança ontológica e da confiança, de modo que "as relações se tornam suspeitas" e haja uma "alienação crescente" (para. 11). Por outro, vê novas oportunidades de ressonância, uma condição em que os humanos ingressam em relações não alienadas com os outros e com o mundo:

Temos tempo. De repente, podemos ouvir e experienciar o que está acontecendo ao nosso redor: talvez realmente ouçamos os pássaros, olhemos as flores e cumprimentemos os vizinhos. Ouvir e responder em vez de dominação e controle são o início de uma relação de ressonância da qual algo novo pode emergir. (para. 13)

\section{Socialismo ou barbárie}

A crise da coronavírus certamente significa que os humanos têm menos relações sociais diretas, se deslocam muito menos, vivem mais localmente e percorrem menos distâncias físicas. Mas isso não implica necessariamente desaceleração da vida social. A velocidade da vida social tem a ver com a quantidade de experiências por unidade de tempo. Mesmo se não nos movermos, podemos viver em uma sociedade de alta velocidade, na qual grandes quantidades de informações são rapidamente processadas e um grande número de decisões são tomadas e muitas ações são realizadas por unidade de tempo. Se o período da crise é ou não uma oportunidade para desacelerar de maneira geral o ritmo da vida moderna é, antes de mais nada, uma questão de economia política. Depende de os governos tomarem ou não medidas que permitam ao ser humano sobreviver sem ter que, constantemente, realizar trabalhos sob condições precárias, ao prover suportes materiais que ajudem a evitar a sobrecarga do indivíduo com a convergência de espaços, tempos e papéis sociais. 
O que os humanos percebem na crise da coronavírus é que a vida, o bem-estar, a saúde e a sobrevivência não são autoevidentes. Essa crise é um confronto radical do indivíduo e da sociedade pela morte. A experiência coletiva do medo da morte pode criar novas formas de solidariedade na sociedade e elementos do socialismo.

A ameaça de infecção viral também deu um tremendo impulso a novas formas de solidariedade local e global, além de deixar clara a necessidade de controle sobre o próprio poder. ... a crise atual demonstra claramente como a solidariedade e a cooperação globais são do interesse da sobrevivência de todos e de cada um de nós. (Žižek, 2020, para. 5 e 16)

Entretanto, se demagogos de direita conseguirem manipular ideologicamente esses medos, a realização de tais potenciais pode ser destruída e possíveis fascismos que dividam a sociedade e promovam a ditadura, o genocídio, a guerra, a desumanidade e o assassinato em massa podem se concretizar. A crise da coronavírus radicaliza as perspectivas para o futuro da sociedade. Isso torna mais provável que estejamos caminhando para o socialismo ou para a barbárie.

\section{Coronavírus, sociedade de risco e sociedade de classe}

A coronavírus e outros riscos também podem atingir os ricos e poderosos, como o príncipe Charles, o príncipe Albert, Boris Johnson, Rand Paul, Michel Barnier ou Tom Hanks. Mas isso não implica, como afirma o sociólogo alemão Ulrich Beck (1992), que vivemos no mundo de uma sociedade de risco sem classes, na qual os riscos à existência afetam a todos igualmente, ignorando o status e a classe.

Os ricos e poderosos têm acesso aos melhores médicos e hospitais privados, podendo escapar dos riscos, enquanto os pobres, os trabalhadores e as pessoas comuns sofrem as consequências da privatização e da mercantilização universal, o que significa que têm maior probabilidade de morrer. A crise da coronavírus mostra mais uma vez que a sociedade de risco é, em primeiro lugar e sobretudo, uma sociedade de classes.

\section{Os mais vulneráveis}

Os mais atingidos pela crise e mais vulneráveis são que não têm uma casa para se abrigar, como os sem-teto e os refugiados que estão fugindo ou vivem em campos de abrigo. É muito difícil para esses grupos se protegerem do vírus. 
Os políticos podem proteger esses grupos vulneráveis - criando e fornecendo instalações adequadas que permitam o distanciamento social - ou abandoná-los, não fornecendo apoio, tendo como consequência a morte de muitos indivíduos vulneráveis. Os seres humanos em países em desenvolvimento enfrentam o problema de, muitas vezes, viverem em espaços superpovoados em metrópoles pobres ou em áreas sem acesso à água, sabão, hospitais, médicos etc. As medidas de proteção, como o distanciamento social e a lavagem das mãos podem, assim, ser mais difíceis nos países em desenvolvimento. A falta de bases materiais de proteção pode, desse modo, afetar e prejudicar especialmente os seres humanos em países e regiões pobres.

\section{A classe trabalhadora na crise da coronavírus}

A vida e o trabalho foram radicalmente transformados na crise da coronavírus. Há trabalhadores que não podem trabalhar em casa e à distância. Dependem da diferenciação dos espaços sociais e das relações sociais diretas para produzir. Os exemplos incluem serviços pessoais (cozinheiros, faxineiros, garçons, empregados de bares, cabeleireiros, agentes de viagens, cuidadores infantis etc.), mão de obra na manufatura, na construção civil, na agricultura, na indústria de processamento de alimentos, na confecção, motoristas, trabalhadores do transporte, coleta de lixo, serviços básicos etc.

Muitas dessas ocupações requerem baixas e médias competências e têm salários bastante baixos. Dado que, devido à crise, muitos locais de trabalho foram fechados, os trabalhadores com os salários mais baixos e com menos qualificação que dependem de relações sociais diretas e do acesso a espaços de trabalho fora de suas casas possuem grande probabilidade de ficarem desempregados. Por exemplo, na Áustria, o número de desempregados cresceu de cerca de 400 para 550 mil em dez dias, em março de 2020 (APA, 2020). A maior parte dos novos desempregados pertencia aos setores econômicos de hospedagem, gastronomia e construção (APA, 2020).

Na crise da coronavírus, especialmente os trabalhadores de escritório altamente qualificados podem continuar trabalhando a partir de suas casas. Isso inclui os empregados registrados e os autônomos. Pense, por exemplo, nas atividades de arquitetos, gerentes, cientistas, engenheiros, designers, professores, acadêmicos, escritores, artistas, analistas, administradores, contadores e trabalhadores financeiros, profissionais de marketing e relações públicas, desenvolvedores de software e outros criadores de bens digitais e serviços, advogados, tradutores, secretárias, digitadores, atendentes de call center, consultores etc. Esses podem, em princípio, trabalhar em casa. Em muitos países, existe uma diretriz ou regra 
geral na crise da coronavírus que diz que quem pode realizar seu trabalho em casa é obrigado ou deve fazê-lo.

Há dois problemas principais enfrentados por esses trabalhadores:

a) podem enfrentar sobrecarga social e psicológica ao tentarem trabalhar em casa, a qual, no momento de uma crise de subsistência, torna-se um espaço convergente de múltiplas atividades, incluindo o cuidado, os trabalhos educativo, assalariado, de sobrevivência etc.

b) devido à relativa paralisação da sociedade, há redução na demanda por serviços, o que significa uma possível diminuição nas fontes de renda de muitos trabalhadores em domicílio.

A forma como os governos apoiam os trabalhadores de colarinho branco e outros na crise da coronavírus é decisiva. As estratégias neoliberais colocam o capital e o crescimento econômico em primeiro lugar, ou seja, os trabalhadores de escritório devem trabalhar em capacidade e ritmo normais em casa e não podem contar com um apoio especial. As estratégias socialistas colocam a sobrevivência, a saúde, o bem-estar e a seguridade social em primeiro lugar e, portanto, apoiam materialmente os trabalhadores de colarinho branco e os demais, para que não sofram o risco da ruína material.

\section{Infraestruturas críticas}

Há uma série de ocupações na organização de infraestruturas críticas necessárias para a sobrevivência da sociedade em uma crise existencial. Esse trabalho fundamental é realizado, por exemplo, por médicos, enfermeiros, cuidadores, parteiras, paramédicos, farmacêuticos, psicólogos, bombeiros, trabalhadores do transporte público, jornalistas, trabalhadores da mídia de serviço público, policiais, produtores de alimentos, trabalhadores da indústria alimentícia, entregadores de comida e trabalhadores de transporte, empregados de supermercados, funcionários dos correios e de serviços de entregas, trabalhadores do saneamento, farmacêuticos, trabalhadores de manufatura e montagem de equipamentos médicos, servidores públicos, trabalhadores de telecomunicações, trabalhadores de emergência, funcionários do setor jurídico etc.

Os trabalhadores em setores críticos de infraestrutura enfrentam um risco maior de adoecer, porque têm mais contatos sociais diretos no trabalho do que os outros; por exemplo, médicos e enfermeiros tratando de pacientes de Covid-19 em hospitais. É importante que governos e organizações façam todo o possível para fornecer equipamentos de proteção, procedimentos e condições de trabalho que os preservem. Um problema particular durante a crise, a falta de equipamentos de proteção resultou em muitos enfermeiros e 
médicos contraindo o vírus. Trabalhadores em infraestruturas críticas mostram o alto nível de solidariedade necessária para garantir a sobrevivência da sociedade e da humanidade. É insuficiente que sejam elogiados publicamente como heróis. A importância crucial de seu trabalho deve ser reconhecida não apenas simbolicamente, mas também econômica e socialmente, por exemplo, com o pagamento de bônus extraordinários, benefícios especiais de aposentadoria etc.

Especialmente em situações de emergência, o fornecimento pelo mercado de infraestruturas essenciais está fadado ao fracasso, porque a forma mercadoria opera com base no princípio do lucro e não no do interesse humano. Assim, na medida em que as principais infraestruturas não são serviços públicos, torná-las propriedade pública, em combinação com o controle dos trabalhadores, é uma medida que coloca o humanismo acima da lógica de acumulação de capital. $\mathrm{O}$ neoliberalismo em países como os EUA e o Reino Unido impediu ou prejudicou a prestação pública de serviços de saúde. Como consequência, há falta de recursos (incluindo humanos e físicos) e de acesso dos indivíduos ao sistema de saúde. Em um estado de exceção, como o da crise da coronavírus, os sistemas de saúde disfuncionais multiplicam o número de mortes. Tornou-se evidente que a universalização da saúde e a apropriação pública do setor assistencial são de fundamental importância para garantir o bem-estar de todos. O escritor e ativista Mike Davis (2020) argumenta, nesse contexto, que a pandemia da coronavírus mostra que "a globalização capitalista agora parece ser biologicamente insustentável na ausência de uma infraestrutura de saúde pública verdadeiramente internacional" (para. 24). Bernie Sanders comentou, nessa perspectiva, sobre a crise da coronavírus:

Milhões de pessoas agora exigem que tenhamos um governo que trabalhe para todos. Qual deve ser o papel da campanha na continuação dessa luta para garantir que os cuidados de saúde se tornem um direito humano, não um privilégio, de que aumentemos o salário mínimo para uma renda de vida, et cetera, et cetera. As pessoas agora entendem que é incompreensível que continuemos sendo o único grande país do mundo a não garantir saúde para todos, que tenhamos uma economia que deixa metade de nosso povo vivendo de ... salário em salário.... Que tipo de sistema é esse em que as pessoas hoje morrem sabendo que estão doentes, mas não vão para o hospital, porque não podem pagar a conta que irão receber? (Sprunt, 2020, para. 11 e 13-14)

A conclusão do programa de Sander é que os países atingidos pela coronavírus devem 
contratar pessoas suficientes para identificar a Covid-19 em cada casa agora e dar-lhes o equipamento de proteção necessário, como máscaras adequadas. Ao longo do caminho, precisamos interromper uma sociedade organizada em torno da expropriação, desde os senhorios até as sanções a outros países, para que as pessoas possam sobreviver tanto à doença quanto à sua cura. (Wallace et al., 2020, para. 16)

A coronavírus torna evidente que o mundo precisa alcançar o direito global à saúde pública, ou seja, saúde pública de alto padrão para todos. "A acumulação infinita de capital colapsa em todo lugar. A única coisa que pode salvar a economia é um governo que financie e estimule o consumismo massivo. Isso exigirá socializar toda a economia ... sem chamá-la de socialismo" (Harvey, 2020, para. 17).

\section{O distanciamento social dos indivíduos idosos, fracos e doentes}

Os idosos e as pessoas que sofrem de doenças cardiovasculares, males respiratórios crônicos, diabetes, câncer ou com o sistema imunológico enfraquecido correm risco especial de morrer de coronavírus. Muitos governos, por isso, recomendaram ou obrigaram a permanência em casa e o isolamento dos grupos de risco. Isso, no entanto, gera o problema de que a redução dos contatos sociais diretos pode ser experimentada como um fardo psicológico. $\mathrm{O}$ uso de tecnologias de comunicação para manter contato com entes queridos e comunidades não é uma solução para a falta de contatos sociais diretos, embora seja um meio de oferecer certos tipos de apoio emocional. Os idosos enfrentam, entretanto, a exclusão digital. $\mathrm{O}$ acesso físico, motivacional e de habilidades desse grupo às tecnologias digitais - como computadores, internet, laptops, tablets, telefones celulares, aplicativos, mídia social etc. - é significativamente menor do que na geração mais jovem. Em 2019, $98 \%$ dos cidadãos da UE com idades entre os 16 e os 24 anos eram usuários da internet, enquanto apenas $60 \%$ das pessoas com idades entre os 65 e os 75 a utilizavam. Na faixa etária de 65-75 anos, 31\% tinham habilidades digitais baixas e 2\% nenhuma habilidade digital (https://bit.ly/3lOQ37F).

Dada a exclusão digital, os idosos correm o risco particular de se sentirem solitários e deprimidos devido ao distanciamento social. Enquanto as estratégias neoliberais simplesmente dizem aos aposentados para se isolarem sem medidas de apoio, uma estratégia socialista planeja medidas para aliviar o fardo psicológico dessa condição. Os exemplos incluem serviços sociais e comunitários que fornecem alimentação, instalam tecnologias comunicacionais fáceis de usar nas residências de membros de grupos em risco, manutenção de contatos diários com esses indivíduos etc. 


\section{As crianças, os jovens e a (e-)aprendizagem na crise da coronavírus}

$\mathrm{Na}$ crise da coronavírus, muitos países fecharam creches, escolas primárias e secundárias, bem como universidades. Em consequência, crianças e jovens precisaram ficar em casa com seus pais. A expectativa geral é que o ensino continue a distância, utilizando e-mail, videoconferência, sistemas de mensagens e variadas tecnologias de e-learning.

O primeiro problema que surge é a necessidade das crianças, especialmente as pequenas, de muita atenção, o que entra em conflito com o trabalho dos pais no domicílio. Estes devem atuar não apenas como trabalhadores e cuidadores, mas também como professores. Uma estratégia socialista deve colocar o cuidado infantil e o bem-estar acima do trabalho. A implicação é que, em uma crise existencial da sociedade, os salários devem continuar a ser pagos e subsidiados por governos sem expectativas de desempenho. Os estados de emergência são rupturas radicais da sociedade e da vida cotidiana. Não se pode esperar que a vida, o trabalho e a educação continuem normalmente. Portanto, também as expectativas de desempenho educacional dos alunos devem ser suspensas ou reduzidas a um nível mínimo. Uma opção viável é fornecer os materiais de aprendizagem e suporte, mas não realizar os exames, passando automaticamente todos os estudantes.

O segundo problema é que o e-learning puramente mediado e virtual tende a ser ineficiente e de difícil organização. Portanto, o aprendizado misto ou híbrido, em que o ensino virtual à distância é combinado com sessões de aprendizado presencial, tornou-se o padrão geralmente aceito em e-learning. A aprendizagem híbrida

é a integração total de atividades presenciais e on-line. . . . A aprendizagem híbrida pode incluir a combinação de atividades individuais e colaborativas, modos de comunicação (verbal e escritos) e uma variedade de cursos presenciais e on-line que compõem um programa misto de estudos. .. . [que] representa um avanço conceitual e prático significativo na melhoria da qualidade do ensino e da aprendizagem ... A grande vantagem da aprendizagem mista é que, embora seja transformadora, se baseia em ideais tradicionais de comunidades de alunos e familiares face a face aprendendo. (Garrison, 2011, pp. $75-76$ e p. 82 )

A radical virtualidade do e-learning na crise da coronavírus facilmente atinge limites e causa problemas. Manter os princípios de desempenho avaliativo, sucesso e reprovação em condições de aprendizagem tão difíceis é contraproducente para o desenvolvimento cultural e social dos jovens. 


\section{As cidades globais e as áreas rurais na crise da coronavirus}

O capitalismo global criou um desnível de poder entre as cidades globais e as áreas rurais. As cidades globais são aglomerações espaciais urbanas de capital, força de trabalho, empresas, bancos, infraestrutura, sedes corporativas, indústrias do setor terciário, serviços financeiros internacionais, infraestrutura de telecomunicações etc. Incluem, por exemplo, Nova York, Londres, Tóquio, Paris, Frankfurt, Zurique, Amsterdã, Los Angeles, Sydney, São Paulo, Cidade do México e Hong Kong. "Quanto mais global a economia se torna, maior o acúmulo de funções centrais em relativamente poucos locais, ou seja, as cidades globais" (Sassen, 1991, p. 5). "A necessidade de minimizar os custos de circulação, bem como os tempos de substituição, promove a concentração da produção dentro de alguns grandes centros urbanos que se tornam, com efeito, as oficinas da produção capitalista" (Harvey, 2001, p. 245). A expansão geográfica anda de mãos dadas com a concentração geográfica (Harvey, 2001, p. 246).

Enquanto a riqueza e o poder se concentram nas cidades globais, há falta de recursos, pessoas e infraestruturas em muitas áreas rurais, o que é uma fonte de problemas sociais. Na crise da coronavírus, as pessoas que moram em cidades globais densamente povoadas estão em desvantagem em comparação com as das áreas rurais. Há uma falta de espaços naturais e jardins acessíveis nas cidades globais, tornando difícil para as famílias e indivíduos que vivem nessas cidades suportarem a quarentena e o isolamento social. É especialmente difícil para quem tem filhos, mas vive em pequenos apartamentos sem acesso a um jardim. Além disso, a alta densidade populacional nas cidades globais torna mais provável e fácil a propagação do vírus do que em áreas rurais escassamente povoadas. As pessoas nas áreas rurais têm menor probabilidade de contrair o coronavírus, além de melhor acesso à natureza, o que torna mais fácil lidar com as medidas de quarentena.

As altamente densas populações humanas podem parecer um alvo fácil. É bem sabido que as epidemias de sarampo, por exemplo, só florescem em grandes centros populacionais urbanos, mas morrem rapidamente em regiões escassamente povoadas. A forma como os seres humanos interagem entre si, se movimentam, se disciplinam ou se esquecem de lavar as mãos afeta a forma como as doenças são transmitidas. (Harvey, 2020, para. 5)

$\mathrm{Na}$ crise da coronavírus, a geografia desigual foi parcialmente revertida no que diz respeito ao número absoluto e relativo de doentes e mortes. As áreas rurais certamente possuem a desvantagem de hospitais menos equipados e avançados, mas seus habitantes têm menor probabilidade de contrair o vírus do que os habitantes das cidades globais. 


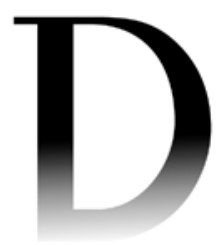

${ }^{2}$ Nesta seção, o autor estabelece uma diferenciação entre false news e fake news, termos traduzidos, respectivamente, como "notícias falsificadas" e "notícias falsas" (N. do T.).

Esta seção abarcou a análise de uma variedade de aspectos da vida e da comunicação cotidiana no cenário da crise. Destacou as profundas mudanças em como o espaço-tempo é organizado nas sociedades afetadas pela pandemia. Tornou-se evidente que o bem-estar das pessoas comuns depende da economia política e das políticas administrativas que os governos adotam em resposta à crise. As respostas políticas à crise variam em um continuum entre o neoliberalismo, de um lado, e o socialismo, do outro. A próxima seção se concentrará em como e que tipo de ideologia é comunicada nesse contexto.

\section{A COMUNICAÇÃO DAS NARRATIVAS DE CONSPIRAÇÃO E AS NOTÍCIAS FALSIFICADAS (FALSE NEWS) DA CORONAVIRUS ${ }^{2}$}

Slavoj Žižek (2020) adverte contra não levar a coronavírus a sério:

Tanto a alt-right quanto a falsa esquerda se recusam a aceitar a realidade total da epidemia, cada qual diluindo-a em um exercício de redução social-construtivista ... Trump e seus partidários insistem continuamente que a epidemia é um complô dos democratas e da China para fazê-lo perder as próximas eleições, enquanto alguns na esquerda denunciam as medidas propostas pelo Estado e pelos aparelhos de saúde como maculadas pela xenofobia e, portanto, insistem nos apertos de mãos etc. Tal postura deixa escapar o paradoxo: não apertar as mãos e entrar em isolamento quando necessário é hoje a forma de solidariedade. (para. 8)

Minimizar e negar a gravidade da coronavírus é uma dimensão ideológica da crise. A disseminação de notícias falsas (fake news) é outra manifestação da ideologia no estado de exceção.

\section{Notícias falsificadas (false news)}

Não existe uma definição geralmente aceita de notícias falsas (fake news). O núcleo de muitas definições é que são notícias factualmente falsas que circulam on-line, predominantemente nas redes sociais, carecem de normas profissionais jornalísticas e tentam sistemática e deliberadamente enganar e desinformar (Fuchs, 2021, capítulo 7). Certos observadores preferem usar os termos informação enganosa ou desinformação. Alguns dos que espalham notícias falsas, como Donald Trump, usam o termo para tentar atacar fontes de notícias confiáveis. Com base na tradição da crítica ideológica que enfatiza que a falsa consciência é uma expressão de tentativas ideológicas de manipular a percepção da realidade do público, uma abordagem de teoria crítica às notícias 
falsas deveria usar, mais adequadamente, o termo notícias falsificadas (false news). As notícias falsificadas são a expressão de um cenário político altamente polarizado, no qual as mentiras são usadas para tentar manipular os resultados eleitorais e a tomada de decisões (Fuchs 2020b).

O escândalo Cambridge Analytica foi uma manifestação típica de notícias falsificadas (Fuchs, 2020b). Na cultura das notícias falsificadas, os fatos são declarados errados e as mentiras são declaradas verdadeiras. Há uma desconfiança em relação a especialistas, liberais e socialistas. Também há uma desconfiança nos fatos e na racionalidade, além da crença de que a verdade é o que se percebe como ideológica e emocionalmente confortável. Os demagogos tentam transformar os especialistas e adversários políticos em bodes expiatórios, alegando que eles formam uma elite que odeia o povo, considerando-o tolo. Espalham informações falsificadas, afirmando que estão do lado das pessoas que compartilham sua ideologia e que as elites deliberadamente distorcem e deturpam a realidade.

A crise da coronavírus criou um estado de exceção em muitos países e partes do mundo. Repentinamente, as vidas cotidianas de bilhões de pessoas foram interrompidas e precisaram ser reorganizadas. As pessoas passaram a temer por suas vidas e pelas vidas de amigos e familiares. Tiveram que pensar em como organizar o cuidado de seus filhos, em como conseguir viver isoladamente, gerenciar melhor as compras, lidar com o estresse psicológico da situação etc. A situação de crise, futuro incerto, choque coletivo e o medo coletivo da morte, característica da emergência da coronavírus, é um campo fértil para a divulgação de notícias falsas. Não sabemos exatamente quais foram as motivações daqueles que divulgaram as notícias falsificadas do coronavírus, mas é possível fornecer uma visão geral dos principais temas das narrativas falsificadas que circularam na época da disseminação global da pandemia ("Misinformation related to the Covid-19 pandemic", 2020).

\section{Os tipos de notícias falsificadas sobre a coronavírus}

Existem dois tipos principais de narrativas noticiosas falsificadas sobre a coronavírus:

a. notícias falsificadas relacionadas à origem da coronavírus;

b. notícias falsificadas sobre como o vírus é contraído e pode ser eliminado.

O primeiro tipo concentra-se em como o vírus corona é produzido, o segundo em como ele circula e como pode ser destruído. 
Narrativas noticiosas falsas sobre a origem da coronavírus:

- O coronavírus é uma arma biológica chinesa desenvolvida no Instituto de Tecnologia de Wuhan.

- O governo chinês colaborou com outros poderes, como o Partido Democrata nos EUA ou o governo norte-coreano, no lançamento do vírus para derrubar Donald Trump.

- A CIA criou e espalhou o vírus como uma arma biológica para intimidar o poder econômico e político da China, Rússia ou Irã.

- Israel desenvolveu e espalhou o vírus para criar uma crise no mercado financeiro e se beneficiar financeiramente da volatilidade resultante.

- Israel ou judeus, como a família Rothschild, desenvolveram o vírus para tomar o poder mundial.

- Espiões chineses roubaram o vírus de um laboratório de pesquisa viral no Canadá.

- O Covid-19 é parte de uma estratégia de controle populacional desenvolvida por Bill Gates e o Instituto Pirbright, financiada pelo governo do Reino Unido.

- Donald Trump criou a pandemia para prender ou matar pedófilos, adversários políticos e atores de Hollywood.

- Comer carne é a causa do coronavírus.

Narrativas noticiosas falsas sobre o contágio e a morte pelo coronavírus:

- Já existe uma vacina contra a infecção.

- A cocaína cura a coronavírus.

- Os africanos são resistentes.

- Redes sem fio 5G causaram o surto de coronavírus.

- Os animais de estimação espalham o coronavírus.

- O vinagre mata o coronavírus.

- Beber gengibre fervido, água com limão ou urina de vaca mata o coronavírus.

- Gargarejo com alvejante mata o coronavírus.

- Ir à sauna mata o coronavírus.

- Usar um secador de cabelo mata o coronavírus.

- Tomar ervas medicinais mata o coronavírus.

- A Sagrada Comunhão protege contra o coronavírus.

- Usar pasta de dente com infusão de prata mata o coronavírus.

- A cura espiritual mata o coronavírus. 
O Breitbart, Rush Limbaugh e as notícias falsificadas sobre a coronavirus

Vamos ver um exemplo de notícia falsificada sobre a coronavírus. O Breitbart é um site de propaganda de extrema direita. Em 27 de março de 2020, era a 256 plataforma web mais acessada no mundo (https://bit.ly/3i0x1Jb). Isso significa que seus relatos alcançam um público bastante grande. Em 24 de fevereiro de 2020, o site publicou uma matéria sobre o apresentador de rádio de direita Rush Limbaugh. O Rush Limbaugh Show possui uma média de mais de quinze milhões de ouvintes, sendo não apenas o talk show radiofônico de maior audiência dos EUA, mas também o programa de rádio mais ouvido no país ("List of most-listened-to radio programs", 2020). Criado em 1988, o programa é um protótipo e principal manifestação da radiodifusão de extrema direita. Ele é veiculado durante a semana e transmitido por cerca de 600 estações de rádio locais.

O título do artigo de Breitbart era "Limbaugh: Coronavirus sendo 'armado' para derrubar Trump" (Key, 2020). Limbaugh afirmou que "provavelmente é um experimento do laboratório ChiCom [comunista chinês] transformado em arma. Todas as superpotências usam armas biológicas.... Parece que o coronavírus está sendo transformado em arma ... para derrubar Donald Trump. Quero contar a verdade" (Key, 2020, para. 2-3). "Algumas pessoas acreditam que foi de propósito, que os ChiComs têm muitos problemas em uma economia que não consegue atender o número de pessoas. Portanto, perder algumas pessoas aqui e ali não é tão ruim para o governo chinês" (I'm Your President, 2020). "O coronavírus é um esforço para deter Trump" (I’m Your President, 2020).

Assim, o que Limbaugh afirma é que a China criou o coronavírus com o fim de atingir os EUA com uma arma biológica e enfraquecer a posição política de Trump, causando muitas mortes. A organização de checagem de fatos PolitiFact analisou as alegações feitas neste episódio do The Limbaugh Show e concluiu que elas eram falsas (McCarthy, 2020).

O Breitbart também fez uso de seus canais de mídia social para divulgar a teoria de conspiração de Rush Limbaugh. Atualmente, o site possui mais de quatro milhões de seguidores no Facebook (https://bit.ly/3gX3JtC), 1,2 milhão no Twitter (https://bit.ly/31WgqR3), 620 mil no Instagram (https://bit. ly/3gZhaJI) e 160 mil assinantes no YouTube (https://bit.ly/353zOxD). Em 25 de fevereiro de 2020, o Breitbart postou um link para a matéria de Limbaugh em sua página do Facebook (veja a figura 3). Em 28 de março, a postagem no Facebook foi compartilhada 900 vezes e recebeu 4.200 reações emocionais e 1.200 comentários. Ao mesmo tempo, 2.279 usuários comentaram a notícia na plataforma Breitbart à qual a postagem do Facebook estava ligada. 


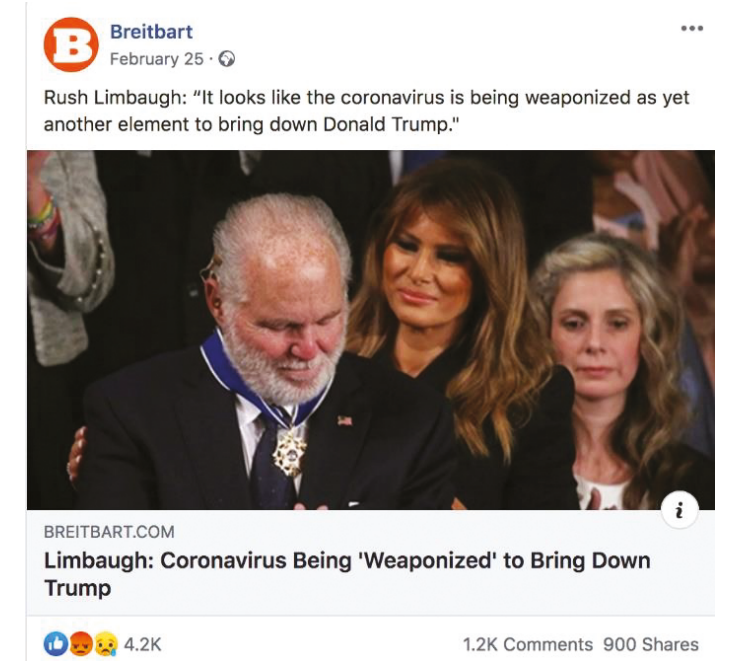

Figura 3

Disseminação da teoria conspiratória de

Rush Limbaugh pelo Breitbart na mídia social

Nota. Imagem de postagem do Facebook do Breitbart (https://bit.ly/2Gk0CPN), acessada em 28 de março de 2020.

O exemplo da alegação conspiratória de Rush Limbaugh de que a China fabricou o coronavírus para derrubar Donald Trump mostra como a extrema direita usa uma combinação de diferentes meios de comunicação para espalhar notícias falsificadas ao público. Nesse caso em particular, o meio de difusão do rádio foi usado para lançar uma notícia falsificada. O Breitbart usou a internet e as redes sociais para divulgá-la. A mídia tradicional e as redes sociais, que permitem comentar e compartilhar, ampliaram conjuntamente o alcance da matéria e, assim, a disseminação da notícia falsificada sobre a doença coronavírus.

Como todas as teorias de conspiração, as afirmações de Limbaugh carecem de evidências e ignoram as descobertas de especialistas. A narrativa está baseada na convicção ideológica e na indignação moral dos apoiadores de Trump, que pensam que há uma grande conspiração por parte de intelectuais, socialistas, liberais e países estrangeiros tentando atacar os Estados Unidos.

As notícias falsificadas ignoram as evidências científicas. Não há indicações de que o coronavírus tenha sido produzido por humanos. Suas sequências de DNA estão mais intimamente relacionadas aos vírus encontrados em morcegos (Cohen, 2020a; Ye, 2020; York, 2020; Zhou 2020). Com base em amostras do ambiente, há evidências de que o vírus foi contraído 
de animais para humanos no mercado de frutos do mar de Wuhan (Cohen, 2020a; Ye, 2020; York, 2020; Zhou 2020). Os cientistas descobriram que animais como o pangolim podem ser as espécies mediadoras da infecção entre morcegos e humanos (Cyranoski, 2020; Lam et al., 2020). Andersen et al. (2020) escrevem com base em uma análise do genoma do vírus que "não acreditam que qualquer tipo de cenário baseado em laboratório seja plausível” (p. 452).

Ignorando a evidência científica, uma variedade de teorias da conspiração surgiu em torno do Covid-19. "As especulações incluem a possibilidade de que o vírus tenha sido produto da bioengenharia no laboratório [Instituto de Virologia de Wuhan] ou que um funcionário dele tenha sido infectado ao manipular um morcego e, depois, transmitido a doença para pessoas fora do laboratório" (Cohen, 2020b, para. 2). Em uma carta ao prestigioso jornal médico The Lancet, 27 cientistas de saúde pública "condenam veementemente as teorias da conspiração sugerindo que o Covid-19 não tem origem natural. ... As teorias da conspiração criam apenas medo, rumores e preconceitos que prejudicam nossa colaboração global na luta contra esse vírus" (Calisher et al. 2020, p. e42). Os cientistas "concluem de forma esmagadora que este coronavírus se originou na vida selvagem" (Calisher et al. 2020, p. e42).

\section{A nacionalismo, o fascismo e a guerra}

A pandemia da coronavírus é uma crise da humanidade. O vírus foi transferido de animais para humanos e, devido ao caráter global e móvel das sociedades, se disseminou globalmente em três meses, causando muitas mortes. Dado que as sociedades contemporâneas não são compostas por nações isoladas, mas envolvem o transporte internacional de mercadorias, pessoas $\mathrm{e}$ viagens globais, um novo vírus pode surgir e, então, se espalhar globalmente a partir de qualquer lugar da Terra. O que a extrema direita tenta fazer é desviar a atenção do fato de que a crise da coronavírus é uma crise da humanidade que só pode ser superada pela solidariedade global e pela ajuda mútua dos entre os seres humanos.

A extrema direita ideologiza o vírus. Declara que ele é um projeto planejado e produzido por uma nação isolada para enfraquecer, atacar e tentar destruir outras nações. Seu objetivo é usar a situação de crise para radicalizar o nacionalismo e disseminar o ódio nacionalista entre as populações de diferentes países. Não é racional supor que um país como a China espalhe um vírus que causa muitas mortes em seu próprio país para atacar outras nações. A coronavírus causou muitas mortes em todas as partes do mundo. 
A ideologia vinculada à coronavírus funciona combinando nacionalismo e pensamento conspiratório. A extrema direita usa a mídia de massa tradicional e a mídia social para propagar o nacionalismo e o ódio no contexto de uma crise da humanidade.

Donald Trump referiu-se repetidamente ao vírus corona como o "vírus chinês" (Mangan, 2020). A Organização Mundial da Saúde condenou esse termo, dizendo que os vírus "não conhecem fronteiras e não se importam com a sua etnia, a cor da sua pele ou quanto dinheiro você tem no banco. Assim, é muito importante que tenhamos cuidado com a linguagem que usamos, para que ela não leve à criação de perfis de indivíduos associados ao vírus" (Kopecki, 2020, para. 2). O perigo da ideologia nacionalista em um Estado de exceção e uma crise da humanidade é que personagens autoritários como Trump estão propensos a usar a violência, podendo resultar em guerras, ataques nucleares, criação de Estados fascistas etc.

Há uma dimensão social da crise da coronavírus: um grande número de pessoas que adoecem gravemente ou morrem. A relativa paralisação da sociedade necessária para conter o vírus se traduz em crise econômica. E há, também, uma dimensão política na crise, na qual o nacionalismo e a ideologia podem causar o surgimento do fascismo e da guerra mundial. Essa doença é um desastre natural que ameaça a humanidade. As reações irracionais - como o nacionalismo, a ideologia e a violência -, entretanto, representam um sério perigo em meio a crises profundas desse tipo. A falta de solidariedade e a substituição dessa pelo nacionalismo podem transformar um desastre natural causador de crises social e econômica em uma crise política que inclui a guerra, os assassinatos em massa, o genocídio e o fascismo.

\section{CONCLUSÃO}

Este artigo indagou: como a vida e a comunicação cotidianas mudaram na crise da coronavírus? Como o capitalismo configura a vida e a comunicação cotidianas durante essa crise? Podemos sintetizar os principais achados:

\section{Distanciamento social:}

O distanciamento social praticado durante a crise da coronavírus não anula a comunicação e as relações sociais, mas substitui a comunicação face a face, que traz o risco de contágio, pela comunicação mediada. O distanciamento social não é o distanciamento da sociabilidade e da comunicação, mas sim uma sociabilidade e comunicação à distância. 


\section{A ruptura da vida e da comunicação cotidianas:}

A crise da coronavírus trouxe uma transformação radical do espaço-tempo da vida e da comunicação cotidianas. Nessa crise, os espaços sociais e os locais de trabalho, lazer, educação, esfera pública, esfera privada, amizades, família convergem para o lar, que assume o papel de supralocal da vida cotidiana, a partir do qual os seres humanos organizam a sociedade à distância com o auxílio das tecnologias de comunicação. As atividades que os humanos geralmente desempenham em diferentes papéis sociais em momentos diversos e em locais variados convergem para atividades conduzidas em um espaço-tempo universal, tendencialmente não zoneado e não estruturado em um local, a casa.

\section{O risco dos indivíduos sobrecarregados:}

A convergência de espaço-tempo no lar, característica da crise da coronavírus, pode facilmente sobrecarregar o indivíduo que não consegue lidar com vários papéis sociais ao mesmo tempo em um único local. As políticas públicas de saúde que aliviem o indivíduo são, portanto, de fundamental importância para o gerenciamento de tal crise.

\section{As tecnologias de comunicação como meio de sociabilidade à distância:}

As tecnologias de comunicação exercem um papel importante na organização da vida social cotidiana nas condições excepcionais colocadas pela crise da coronavírus para a sociedade e os indivíduos. Os meios de comunicação primários são, em geral, evitados. Existe o amplo uso da comunicação mediada com o auxílio de meios de comunicação secundários, terciários, quaternários e quinários. A comunicação face a face é substituída pela comunicação mediada, o que cria desafios, já que a proximidade, o amor e as emoções são difíceis de alcançar e comunicar na comunicação mediada. Não é possível abraçar alguém pela internet.

\section{A coronavírus e as estruturas de classe:}

Embora todos possam contrair a coronavírus, os efeitos sociais da pandemia estão distribuídos desigualmente pelas estruturas de classe. Os pobres, os velhos, os fracos e os doentes são especialmente vulneráveis e afetados. Enquanto alguns trabalhadores podem continuar a trabalhar em domicílio, mas enfrentam o perigo da sobrecarga de atividades e da falta de demanda, outros perdem seus empregos e enfrentam o risco da miséria, do desemprego e da falta de moradia. 


\section{As medidas governamentais:}

As respostas governamentais à crise da coronavírus variam em um continuum entre o neoliberalismo e o socialismo. As estratégias neoliberais podem ser encontradas, por exemplo, no Reino Unido, onde é adotada uma abordagem laissez-faire que evita modificar a vida cotidiana e coloca o crescimento econômico e o lucro como um imperativo acima dos interesses e das vidas humanas. Cada um é deixado por sua própria conta, ou seja, só os fortes sobrevivem. Essas respostas deixam claro que o neoliberalismo é uma forma de darwinismo social. As estratégias socialistas baseiam-se na ideia de solidariedade coletiva na luta contra a pandemia. São tomadas medidas para minimizar o número de mortos e tentar salvaguardar uma vida boa para todos. As vidas e os interesses humanos são colocados acima dos interesses capitalistas. A crise da coronavírus é uma crise existencial da humanidade e da sociedade. Logo, as medidas socialistas visam fornecer recursos e formas de alívio ao ser humano para garantir o tempo necessário para o trabalho de sobrevivência, a fim de melhor enfrentar as dificuldades das rupturas da vida cotidiana, sendo mais capaz de reorganizar as atividades rotineiras, lidar com medos e ansiedades, apoiar amigos, família e comunidades etc.

\section{Notícias falsificadas sobre a coronavírus:}

O choque e o medo coletivos da morte que emergiram na crise da coronavírus são um terreno fértil para a divulgação de notícias falsificadas sobre a doença.

\section{Tipos de notícias falsificadas sobre a coronavírus:}

Existem dois tipos principais de notícias falsificadas sobre a coronavírus:

a. notícias falsificadas relacionadas à origem do coronavírus;

b. notícias falsificadas sobre como o vírus é contraído e como pode ser eliminado.

A comunicação da extrema direita de notícias falsificadas sobre a coronavírus:

A extrema direita aproveitou a crise da coronavírus para propagar o nacionalismo e o ódio, comunicando notícias falsificadas sobre o coronavírus por meio das mídias tradicional e social. 


\section{Socialismo ou barbárie}

A crise da coronavírus é uma crise existencial da humanidade e da sociedade. Ele confronta radicalmente os humanos com a morte e o medo da morte. Essa experiência coletiva pode, por um lado, resultar em novas formas de solidariedade e socialismo. Os seres humanos percebem que a vida, o bem-estar, a saúde e a sobrevivência são seus bens mais importantes e fundamentais, que precisam cuidar de si mesmos e uns dos outros e que a solidariedade coletiva e global é necessária para superar a pandemia.

Entretanto, por outro lado, existe o risco da guerra e do fascismo. O maior perigo político da crise da coronavírus é que a extrema direita utilize o estado de emergência para espalhar notícias falsificadas, nacionalismo e ódio, provocando violência, guerra, ditadura, genocídio e fascismo. A crise da coronavírus radicaliza as perspectivas para o futuro da sociedade. Isso torna mais provável que estejamos caminhando para o socialismo ou para a barbárie. Assim como há cem anos, a sociedade burguesa também hoje e nos tempos vindouros "está na encruzilhada, na transição para o socialismo ou na regressão à barbárie" (Luxemburgo, 1916, p. 388). "Nesta hora, o socialismo é a única salvação para a humanidade” (Luxemburgo, 1971, p. 367). M

\section{REFERÊNCIAS}

Andersen, K. G. (2020). The proximal origin of SARS-CoV-2. Nature Medicine, 25, 450-452. https://doi.org/10.1038/s41591-020-0820-9

Austria Press Agency (APA). (2020, 25 de março). 153.100 mehr Arbeitslose seit 15. März. Wiener Zeitung. https://bit.ly/3jIIZYn

Beck, U. (1992). Risk society: Towards a new modernity. Sage.

Calisher, C. et al. (2020). Statement in support of the scientists, public health professionals, and medical professionals of China combatting Covid-19. The Lancet, 395(10226), e42-e43. https://doi.org/10.1016/S0140-6736(20)30418-9

Cohen, J. (2020a, 31 de janeiro). Mining coronavirus genomes for clues to the outbreak's origins. Science Magazine. https://bit.ly/31Xkh0c

Cohen, J. (2020b, 19 de fevereiro). Scientists "strongly condemn" rumors and conspiracy theories about origin of coronavirus outbreak. Science Magazine. https://bit.ly/2Z3vw5D

Coronavirus pandemic in mainland China. (2020). In Wikipedia. https://bit. ly/2Z7RnJ7, acesso em 27 mar. 2020.

Cyranoski, D. (2020). Mystery deepens over animal source of coronavirus. Nature, 579, 18-19. https://doi.org/10.1038/d41586-020-00548-w

Davis, M. (2020, 14 de março). In a plague year. Jacobin. https://bit.ly/3hlpQz8 
Fuchs, C. (2020a). Communication and capitalism: A critical theory. University of Westminster Press.

Fuchs, C. (2020b). Nationalism on the internet: Critical theory and ideology in the age of social media and fake news. Routledge.

Fuchs, C. (2021). Social media: A critical introduction ( $3^{\mathrm{a}}$ ed.). Sage.

Galton, F. (1909). Essays in in eugenics. The Eugenics Education Society.

Garrison, R. D. (2011). E-Learning in the 21st century. A framework for research and practice ( $\left.2^{\mathrm{a}} \mathrm{ed}.\right)$. Routledge.

Giddens, A. (1984). The constitution of society: Outline of the theory of structuration. Polity.

Harvey, D. (2001). Spaces of capital: Towards a critical geography. Routledge.

Harvey, D. (2005). Space as keyword. In D. Harvey, Spaces of neoliberalization (pp. 93-115). Franz Steiner Verlag.

Harvey, D. (2020, 20 de março). Anti-capitalist politics in the time of Covid-19. Jacobin. https://bit.ly/2Z4WNog

I'm Your President. (2020, 24 de fevereiro). The Rush Limbaugh Show 2/24/20 EIB podcast [Vídeo]. YouTube. https://bit.ly/2EWYEVh

Key, P. (2020, 24 de fevereiro). Limbaugh: Coronavirus being "weaponized" to bring down Trump. Breitbart. https://bit.ly/3jLLXeU

Kopecki, D. (2020, 18 de março). WHO officials warn US President Trump against calling coronavirus the "Chinese virus". CNBC. https://cnb. $\mathrm{cx} / 31 \mathrm{VN} 19 \mathrm{E}$

Lam, T. T.-Y. et al. (2020). Identifying SARS-CoV-2 related coronaviruses in Malayan pangolins. Nature, 583, 282-285. https://doi.org/10.1038/ s41586-020-2169-0

Lefebvre, H. (1991). The production of space. Blackwell. (Obra original publicada em 1974)

Lefebvre, H. (2002). Critique of everyday life. Volume II: foundations for a sociology of the everyday. Verso.

List of most-listened-to radio programs. (2020). In Wikipedia. https://bit.ly/2QS1UUr, acesso em 27 mar. 2020.

Luxemburgo, R. (1916). The Junius pamphlet. In R. Luxemburgo, Rosa Luxemburg speaks (pp. 371-477). Pathfinder.

Luxemburgo, R. (1971). Selected political writings of Rosa Luxemburg. Monthly Review Press.

Mangan, D. (2020, 19 de março). Trump blames China for coronavirus pandemic: "The world is paying a very big price for what they did". CNBC. https://cnb.cx/2EZzdCz 
McCarthy, B. (2020, 27 de fevereiro). Fact-checking Rush Limbaugh's misleading claim that the new coronavirus is "the common cold". PolitiFact. https:// bit.ly/2F8Kos4

Mies, M., Bennholdt-Thomsen, V., \& Werlhof, C. (1988). Women: The last colony. Zed Books.

Misinformation related to the Covid-19 pandemic. (2020). In Wikipedia. https:// bit.ly/3hYSvpN, acesso em 27 mar. 2020.

Organização Mundial da Saúde (OMS). (2020, 12 de março). WHO announces Covid-19 outbreak a pandemic. WHO. https://bit.ly/3gWNnkR

Rosa, H. (2020a, 18 de março). Interview. Philosophie Magazin. https://bit. ly/3jO3NOn

Rosa, H. (2020b, 25 de março). Interview. TAZ. https://bit.ly/3boGYh4

Sassen, S. (1991). The global city. NJL Princeton University Press.

Sky News (2020, 13 de março). UK needs to get Covid-19 for "herd immunity" [Vídeo]. YouTube. https://bit.ly/2Z2Vmqc

Sprunt, B. (2020, 27 de março). Bernie Sanders on his campaign: "It's going to be a very steep road". NPR. https://n.pr/2Z7qd50

Wallace, A. R. (2009). Darwinism. Cambridge University Press. (Obra original publicada em 1889)

Wallace, R., Liebman, A., Chavez L. F., \& Wallace, R. (2020). Covid-19 and circuits of capital. Monthly Review, 72(1). https://bit.ly/3h5sRyF

Ye, Z.-W. et al. (2020). Zoontic origins of human coronavirus. International Journal of Biological Sciences, 16(10), 1686-1697. https://dx.doi. org/10.7150\%2Fijbs. 45472

York, A. (2020). Novel coronavirus takes flight from bats? Nature Reviews Microbiology, 18, 191. https://doi.org/10.1038/s41579-020-0336-9

Zhou, P. et al. (2020). A pneumonia outbreak associated with a new coronavirus of probable bat origin. Nature, 579, 270-273. https://doi.org/10.1038/ s41586-020-2012-7

Žižek, S. (2020, 16 de março). Monitor and punish? Yes, please! The Philosophical Salon. https://bit.ly/3i0ZheW

Artigo submetido em 31 de agosto e aprovado em 20 de setembro de 2020. 